\title{
Farming into the future - innovation technology and efficiency
}

\author{
Patitapu Station, Alfredton \\ joanddoug@wizbiz.net.nz
}

My wife Jo and I are shareholding managers of Patitapu Station at Alfredton in the North Wairarapa. It is a family business consisting of 2550 ha (1760 ha effective) predominately hill country, approximately half way between the Tararua ranges and Castlepoint. It runs 17500 s.u, $75 \%$ sheep, $25 \%$ cattle, predominantly breeding with some finishing. It is highly variable in terms of contour, aspect, soil type, altitude and climate. Patitapu was purchased and developed by my father from 2000. This development has covered all aspects of the farm. With Wairere as an example on our southern boundary, the backbone of the development plan was traditional with the tried and true recipe of fencing/water, fertiliser/lime and hoof and tooth pasture development. A 200 ha block was roller crushed and developed out of gorse and scrub. All of the infrastructure has been upgraded, flock genetics changed and 120 ha of cultivatable ground brought in.

My background prior to managing Patitapu was as a Rural Manager for the National Bank so my approach to the farm has taken on more of a business based orientation, which has included significant off-farm investments into dairy. The involvement in both industries provides an interesting insight into the strengths, weaknesses and opportunities of each industry.

The key focus on Patitapu is that it is run as a high performing farming business as opposed to a medium/low performance station with "station based" mentalities (Table 1, Figure 1).

My focus is around achieving the five E's:

- Enjoyment: For staff, stakeholders, contractors and wider relationships.

- Economics: Actively managing, and achieving targets with regards to both the cash and capital sides of the business.

- Effective: Producing and achieving functions and targets with the available resources.

- Efficient: Using resources to their optimum level: land, labour, capital.

- Environment: Sustainability and repeatability.

\section{New Technologies and innovations}

Technology is changing very fast. As an example, when I left the bank in 2008, there were no smart phones or reliable internet access at the farm. Whilst at the time this was a refreshing change from corporate life, the business now struggles to operate for even a short period of time without these modern essentials. As another example, my father now in his $60 \mathrm{~s}$ recalls the two biggest advancements to his farming progress as being the electric fence and the pocket calculator! We need to be careful not to limit our thinking as to what is potentially possible when looking forward 10-20 years time.

Types of advancement:

- Management practices.

- Products and services.

- Integration of the two.

Table 1 Patitapu Station: Key Performance Indicators: Maximum (2014/15), Minimum (2010/11) and 6 year average (2009/10 to $2014 / 15)$.

\begin{tabular}{|c|c|c|c|}
\hline Year & $\begin{array}{c}6 \text { year } \\
\text { Average }\end{array}$ & 2014/15 & 2010/11 \\
\hline kg LW/ha May 30 & 643 & 665 & 613 \\
\hline S.U./ha May 30 & 9.6 & 10 & 9 \\
\hline Av. LW/ha 12 mths & 664 & 707 & 610 \\
\hline Scanning & 173 & 175 & 174 \\
\hline Lambing \% & 138 & 144.6 & 131 \\
\hline Hgts fm Scan ${ }^{1}$ & 71 & 60 & 72 \\
\hline Calving & 91 & 95 & 92 \\
\hline Lambs Sold & 10963 & 11888 & 10058 \\
\hline Av Price & $\$ 87.73$ & $\$ 85.03$ & $\$ 90.84$ \\
\hline Av LW Sales & 35.4 & 35.3 & 32.6 \\
\hline Av $\$ / k g$ LW & $\$ 2.47$ & $\$ 2.41$ & $\$ 2.78$ \\
\hline Prime/Store & $42 / 58$ & $37 / 63$ & $28 / 72$ \\
\hline kg product/ha unadj & 206 & 231 & 181 \\
\hline price/kg product & $\$ 5.01$ & $\$ 5.09$ & \\
\hline milk $\$ / k g C^{2}$ & $\$ 6.85$ & $\$ 6.07$ & $\$ 7.56$ \\
\hline $\mathrm{GFI} / \mathrm{ha}^{3}$ & $\$ 953$ & $\$ 1,090$ & $\$ 880$ \\
\hline FWE/ha ${ }^{4}$ & $\$ 556$ & $\$ 607$ & $\$ 503$ \\
\hline $\mathrm{EFS}^{5}$ & $\$ 412$ & $\$ 483$ & $\$ 377$ \\
\hline
\end{tabular}

${ }^{1}$ Hoggets

${ }^{2} \$$ per $\mathrm{kg}$ MS in cashflow season

${ }^{3}$ Gross farm income/ha

${ }^{4}$ Farm Working Expenses

${ }^{5}$ Effective farm surplus/ha 

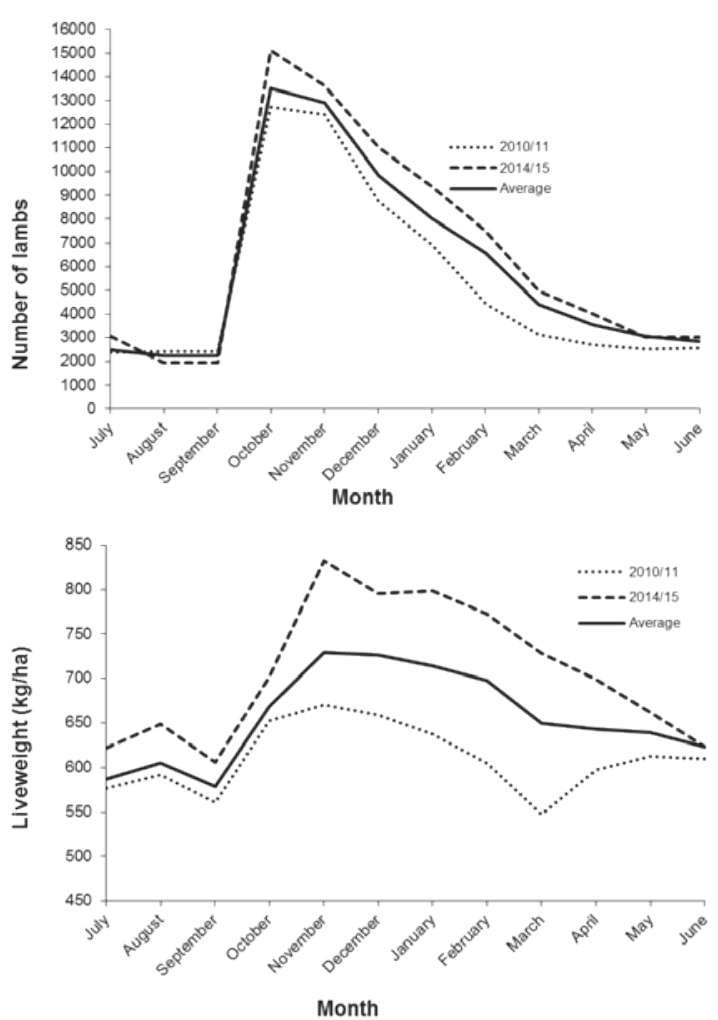

Figure 1 Patitapu Station monthly lamb numbers (above) and $\mathrm{Kg}$ liveweight/ha carried (below) over the last 6 years: maximum (2014/15), minimum (2010/11) and 6-year average (2009/10-2014/15).

With so many new innovations, some become mainstream, others fade away for a variety of reasons. In terms of uptake there are influencing factors from both the farmer's perspective and also on the side of the new technology or innovation. The mix and interrelationship between "sales" and "science" is a very large complication to this matter.

Farmers have differing views with regard to what to take up and when. This could be relative to their physical and financial position or their personal situation or personality type. From the new technology point of view, factors which primarily affect uptake include total or marginal cost, cost versus return, complexity or simplicity, compliance and regulation, marketing and industry trends.

With regard to the adoption of new technology, there are four types of farmers:

1. Those who innovate or seek out and adopt new technologies and practices early and enjoy the experimentation phase.

2. Those who are "sold" new technologies or practices. This can create positive and negative experiences depending on how it is done, and who is targeted.
3. Those who don't like or want to change from the status quo, and may only change once something has become "mainstream" or not at all.

4. Those who sit back and watch the initial stages of new technologies and then make an informed assessment as to whether to be a fast follower or not once the initial trial and error period has been completed.

I firmly place myself in group four, due to the forementioned goals of the $5 \mathrm{Es}$, and a focus on keeping a simple repeatable system given a range of controllable and uncontrollable variables.

\section{Bridging the gap - New innovations and technology in hill country sheep and beef}

One of the key limitations to hill country sheep and beef farming is the variation and averaging affect. Our class of country relies more heavily on an individual farmers' experience, competence and "gut feeling" than other classes of country.

Generally speaking we are looking at average mob liveweight (LW) or condition score. Average soil and pasture tests over wide and varied areas. Average flock, area or class production and performance. Compare this to the specific management of a dairy farm or a precision cropping farm.

Dairy farms have a centralised paternal breeding plan (LIC). They also have individual maternal based information. Cow production, LW and somatic cell counts can be monitored and managed daily on an individual basis (via electronic ID and in-shed computer technology). Farms can be cost effectively mapped, soil tested and differing fertiliser mixes and application rates applied on a "paddock specific" basis. Often paddocks or whole farms can be drained, irrigated and enhanced with new pasture varieties or crops. The combination of the above means that in terms of pasture production per ha, product per ha and gross earning power per ha is marginally greater than just the "unchangeable" environmental factors would suggest.

If you combined these attributes and assume the same income per $\mathrm{kg}$ of product of say $\$ 5.50 / \mathrm{kg}$, it gives the following crude example on a gross per ha production and income basis:

- 1 ha Dairy: Pasture production 16 t. Milk solids production at $3 \mathrm{cows} / \mathrm{ha}$ and $400 \mathrm{~kg} / \mathrm{cow}=1200 \mathrm{~kg} /$ ha milk $+210 \mathrm{~kg} / \mathrm{ha}$ stock $=1410 \mathrm{~kg} /$ ha product @ $\$ 5.50 \mathrm{~kg}=\$ 7755$. Scale to $70 \%$ to allow for support land $=987 \mathrm{~kg}$ product, $\$ 5428 / \mathrm{ha}$ or $\$ 0.34 / \mathrm{kg}$ total DM. The dairy example has been scaled at $70 \%$ allowing for approx. 0.8 ha of support land per ha of milking platform at a lower pasture production level.

- 1 ha High performance finishing land: Pasture production say $12 \mathrm{t}$. Meat and fibre production say $500 \mathrm{~kg}$ product @ $\$ 5.50=\$ 2750 / \mathrm{ha}$ or $\$ 0.24 / \mathrm{kg}$ total DM. 
- 1 ha Hill country sheep and beef: Av. LW/ha carried $=700 \mathrm{~kg}$. Pasture production say $7.5 \mathrm{t}$. Meat and fibre production say $220 \mathrm{~kg}$ product @ $\$ 5.50=\$ 1210 / \mathrm{ha}$ or $\$ 0.16 / \mathrm{kg}$ total DM.

Not only are the more intensive properties growing more grass, they convert it more efficiently and so get paid more on a $\mathrm{c} / \mathrm{kg} \mathrm{DM}$ basis. Whilst it is perhaps unrealistic to attempt to bring the three respective industries onto a par, the key is around focusing on technologies and advancements to bridge the gap and have hill country sheep and beef farms producing at their maximum efficiency. For some areas that may be forestry, carbon, manuka honey or some other as yet to be discovered industry as opposed to pastoral farming.

A range of technologies and advancements are addressing these limitations. For example SIL, Farm IQ, Farmax, hill country cropping, new pasture and crop varieties, condition scoring practices and machines, on farm GR measurements, more effective and detailed topographical mapping of areas including slope and aspect etc. The list goes on and many people and organisations need to be commended for this progress. It is however well documented that New Zealand's spend on R\&D in general is significantly behind that of other countries, and our rate of agricultural growth has slowed.

\section{Base knowledge of your physical resources}

We are currently in the early stages of being a Ravensdown trial property for their PGP project on remote sensing technology and variable rate spreading. This is being run in conjunction with AgResearch and Massey University. This technology has the potential to be a major leap forward in how nutrients and pastures are managed on hill country properties.

The basics of any pasture-based system come down to the interrelationship between the climate, soils, pastures and management. This delivers a pasture production curve which is not only specific for that farm but also specific down to an individual paddock and an internal paddock level.

At the most simplistic level there exists a farm map and an effective area. Secondly comes the range of land quality within this area subject to a range of variables. How accurately these two things are known (or unknown) has the greatest effect on the potential production levels and the highest and best system for that specific property. This flows onto earning potential and hypothetically capital value.

The potential to be able to practically and cost effectively map and manage to a much more detailed level large areas of hill country, allowing for changes in aspect, altitude, slope, soil type, soil fertility, pasture species etc is very exciting. It has wide ranging potential to change hill country from both a production and an economic point of view.

Possible benefits from remote sensing technology and detailed mapping:

- Understanding pasture and soil fertility composition.

- A greater understanding of both whole farm and individual paddock features. Allows for farm system or specific paddock adjustments.

- Property valuations based more on more detailed knowledge of key features such as \% aspect, slope, fertility, DM production etc.

- Better understanding of nutrient transfer via stock and/or runoff.

- Fast objective assessment of feed volume and quality.

- Better cost benefit analysis of potential development programs on different areas.

Possible benefits from variable rate fertiliser:

- More targeted applications where particular nutrients are needed, e.g. slope, soil type or aspect specific.

- A reduction or redistribution of nutrients. Versus the averaging effect.

- Less wastage into non-productive areas.

- Less environmental impact from runoff, or fertilising sensitive areas.

- Higher production and profit via enhancement of low performing areas.

\section{Conclusion}

Technology and innovation will continue to advance farm business development. As an industry we need to be careful not to set limitations based on todays technology and thinking. Collaboration between farmers, industry organisations and science is crucial to keep New Zealand maintaining its competitive advantages over our competitors. Based on Beef + Lamb's economic service, $49 \%$ of farms in New Zealand are classed as "hill country" or "hard hill country". By scale and gross area there exists a massive opportunity to raise the bar on this class of country with more targeted and specified management, knowledge and technologies. 
